Surlyk, F. 1975: Block faulting and associated marine sedimentation at the Jurassic-Cretaceous boundary, East Greenland. In Finstad, K. G. \& Selley, R. C. (edit.) Jurassic northern North Sea symposium 1975 (JNNSS-75). Norwegian Petroleum Society, JNNSS/7, 1-31.

Surlyk, F., Callomon, J. H., Bromley, R. G. \& Birkelund, T. 1973: Stratigraphy of the Jurassic - Lower Cretaceous sediments of Jameson Land and Scoresby Land, East Greenland. Bull. Gronlands geol. Unders. 105, 1-76.

Surlyk, F., Clemmensen, L. B. \& Larsen, H. C. 1981: PostPaleozoic evolution of the East Greenland continental mar- gin. In Kerr, J. W. \& Ferguson, A. J. (edit.) Geology of the North Atlantic borderlands. Mem. Can. Soc. Petrol. Geol. 7, 611-645.

Surlyk, F. \& Zakharov, V. A. 1982: Buchiid bivalves from the Upper Jurassic and Lower Cretaceous of East Greenland. Palaeontology 25, 727-753.

Sykes, R. M. \& Brand, R. P. 1976: Fan-delta sedimentation: an example from the late Jurassic - early Cretaceous of Milne Land, central East Greenland. Geologie en Mijnbouw 55, 195-203.
F. S.,

Grønlands Geologiske Undersøgelse,

$\emptyset$ ster Voldgade 10 ,

$D K-1350$ København $K$,

Danmark.
N. N.-N., Inst. for Historisk Geologi og Palaontologi, $\emptyset$ ster Voldgade 10, $D K-1350$ København $K$, Danmark.

\title{
Sedimentological studies of the Upper Triassic to Lower Jurassic succession in the Jameson Land Basin, central East Greenland
}

\author{
Gregers Dam
}

Sedimentological studies of the Upper Triassic to Lower Jurassic succession in central East Greenland were initiated in 1987 as a three-year research fellowship programme supported by British Petroleum Development, London (Dam, 1988). The study is primarily a lithofacies analysis, but ichnology, palynology sourcerock analysis, porosity/permeability analysis and diagenetic studies are also included in the programme. The stratigraphic interval includes the Kap Stewart and Neill Klinter Formations which have many features in common with stratigraphically equivalent formations in offshore mid- and northern Norway that form some of the most important potential petroleum reservoirs in these areas.

The field work in 1988 was carried out by the author accompanied by A. Boesen, and lasted for 7 weeks from late June to late August but was impeded in a threeweek period by bad weather in the region.

The 1988 activities were concentrated in three main areas; along the west coast of Hurry Inlet, in Lepidopteriselv and Liaselv just west of Carlsberg Fjord, and in Ranunkeldal, a tributary valley to Schuchert Dal (fig. 1). Sedimentological studies involved detailed lithofacies and ichnofacies analyses as well as sampling for palynofacies analyses, source rock analyses and reservoir rock properties.

\section{Geological setting}

The sediments of the Kap Stewart and Neill Klinter Formations were laid down in the Jameson Land Basin in central East Greenland, where they constitute the lowermost two formations of the Jameson Land Group (Surlyk et al., 1973). In age the formations span most of the Rhaetian-Toarcian interval. Their setting in the Jameson Land basin was reviewed by Dam (1988).

\section{Kap Stewart Formation}

Seven facies associations are here recognized in the Kap Stewart Formation:

(1) Lacustrine (prodelta) association; (2) Interdistributary bay association; (3) Longshore directed shoal association; (4) Beach face association; (5) Distributary channel association; (6) Interdistributary area association; (7) Delta abandonment association.

Vertical and lateral distributions of environments. Along Hurry Inlet in the southeastern part of the basin the Kap Stewart Formation is approximately $200 \mathrm{~m}$ thick. In this area Harris (1937) subdivided the formation into an upper 'plant-bearing-series' and a lower 'barren sandstone'. Although this division has not been adopted in recent literature (Surlyk et al., 1973; Pe- 


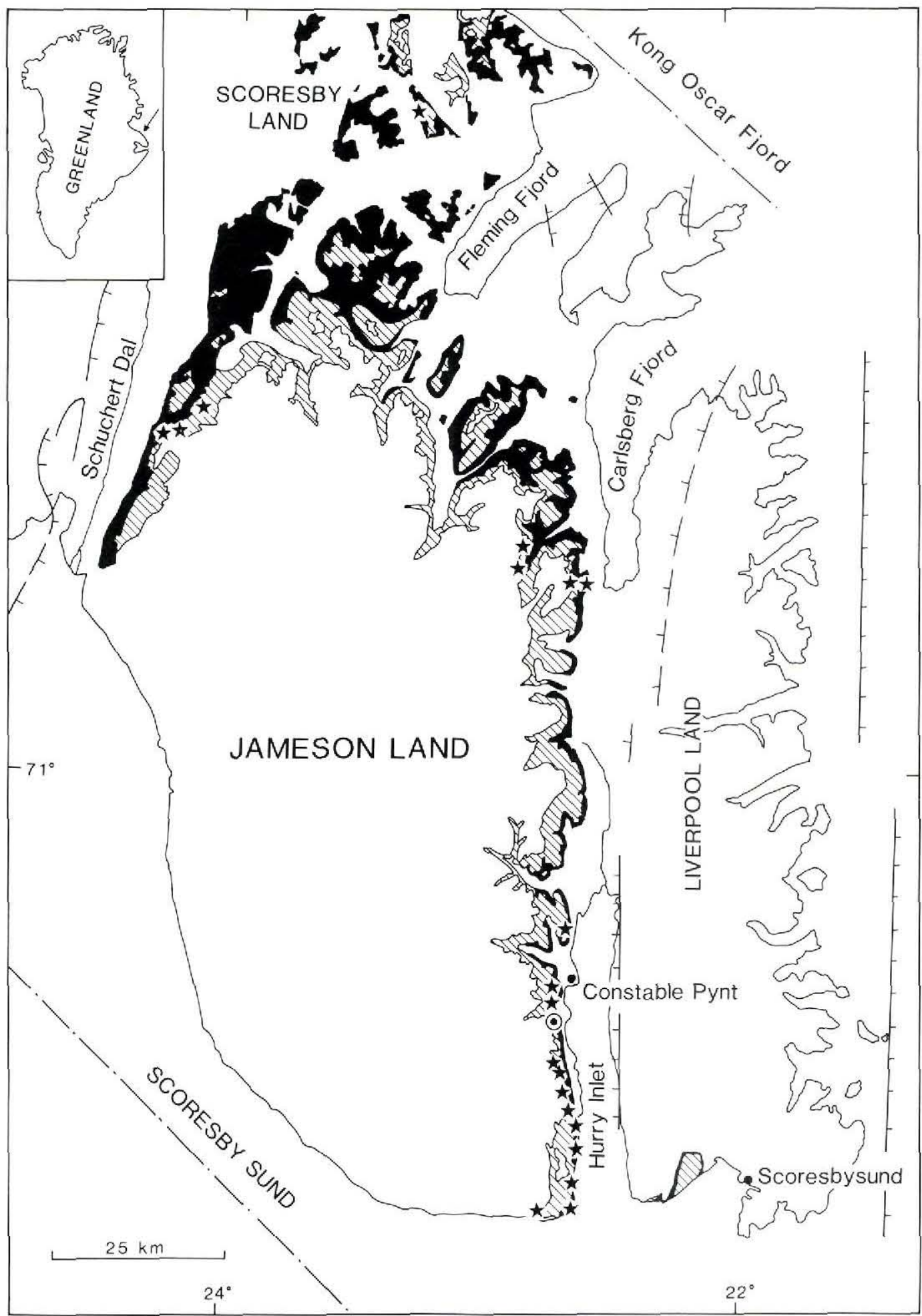

Neill Klinter Formation

$\star$ Measured section

Kap Stewart Formation

- Cored section

Fig. 1. Map of Jameson Land showing outcrops of the Kap Stewart and Neill Klinter Formations, localities, and major faults based on Surlyk et al. (1981). 
dersen \& Lund, 1980) it does separate conglomeratic sheet-formed sandstone bodies below from well-developed fining upwards (FU) sequences above. The lower unit was deposited in a braided alluvial system draining an eastern landmass. The coarse-grained alluvial deposits show an upward gradational passage into delta plain deposits characterized by overbank fines and a lowsinuosity to braided river sediments. Palaeocurrent directions indicate an eastern source area.

In the western part of the basin the formation is approximately $155 \mathrm{~m}$ thick and, as in the southeastern part, constitutes a major FU sequence. The formation has lower and upper gradational contacts to the Fleming Fjord and Neill Klinter Formations respectively. Here the lowermost two-thirds of the succession are dominated by interdistributary bay, lacustrine beach face, distributary channel and delta abandonment deposits. Palaeocurrent directions indicate a westerly palaeodrainage. The uppermost approximately $40 \mathrm{~m}$ are dominated by lacustrine shales interrupted only by one sheet composed of longshore sandy shoal deposits. Both the lacustrine shales and the sandy shoal deposits have been followed for more than $5 \mathrm{~km}$ into the basin without any lateral thinning, and the lacustrine shales are believed to cover most of the central part of the basin.

In the central to eastern part of the basin a rather similar sequence is developed. Thus basal delta plain and delta front deposits are overlain by a thick lacustrine shale sequence (approximately $20 \mathrm{~m}$ ).

In the northern part of the basin the formation is about $350 \mathrm{~m}$ thick (Surlyk et al., 1973). The overall FU tendency is not as pronounced here as in the central and southern parts of the basin. The succession is composed of alternating wave-dominated delta front and lacustrine deposits. The delta front deposits are composed of interdistributary bay, beach face, distributary channel and delta abandonment facies, whereas the lacustrine deposits are composed of shales and longshore sandy shoal facies. The delta front facies are arranged in sand sheets, 2-10 $\mathrm{m}$ thick, which have been followed for more than $1 \mathrm{~km}$ without lateral thinning. Locally there is a lateral downcurrent change from distributary channel to beach face facies within the sheets. Palaeocurrent directions indicate a northern source area.

Following Norian-Rhaetian? cross-fault activity (Surlyk et al., 1981) fluvial sediments were shed into the basin, both axially from the north, and transversly from east and west. There does not seem to be any hiatus between the Carnian-Norian? Fleming Fjord Formation and the Rhaetian-Hettangian/Sinemurian? Kap Stewart Formation, and restricted lacustrine conditions may have existed over a long period in the central part of the basin. With time the coarse-grained marginal sediments were gradually overlapped by finer-grained delta plain deposits in the southern part of the basin and by lacustrine deposits in the central and northern parts of the basin. The change from a fluvio-deltaic to a lacustrine environment (in the central and northern parts of the basin) might explain the change from the Lepidopteris and Thaumatopteris floras in the southern part of the basin. However, the exact age of the lacustrine shales is needed to support this interpretation. The overall regressional trend is probably related to retreat of the source area, or increasing humidity, or both.

The gradual change to marine conditions marked by the change from the Kap Stewart to the Neill Klinter Formation in the central and northern parts of the basin is probably related to a regional sea-level rise. In the southern part of the basin this change is marked by an unconformity between the two formations.

\section{Neill Klinter Formation}

The Neill Klinter Formation was defined by Rosenkrantz (1929) and consists of three members (Surlyk et al., 1973): the Rævekløft Member (base), the Gule Horn Member and the Ostrea Elv Member (top).

The following facies associations were recognized in the formation.

Ravekløft Member: Wave-influenced beach face association.

Gule Horn Member: (1) Storm-influenced shelf association; (2) Tidal sand ridge association; (3) Subtidal sand sheet association; (4) Wave- and tide-influenced delta front association.

Ostrea Elv Member: (1) Fan delta association; (2) Bioturbated shelf sand association; (3) Storm-influenced shelf association.

Vertical and lateral distributions of environments. Along Hurry Inlet there is a marked unconformity between the delta plain deposits of the Kap Stewart Formation and the beach face deposits of the Rævekløft Member (Surlyk et al., 1973). This member is approximately $15 \mathrm{~m}$ thick in Ravekløft (Surlyk et al., 1973) at the mouth of Hurry Inlet, and thins to approximately 4-9 m at Constable Pynt. The Rævekløft Member cannot be traced north of Constable Pynt. Palaeocurrent directions are predominantly towards the north and northeast.

In the central and northern parts of the basin there is a gradational boundary between the lacustrine deposits of the Kap Stewart Formation and the shelf and deltaic 
deposits of the Gule Horn Member. The Gule Horn Member has a very uniform thickness throughout the basin, ranging from $150-170 \mathrm{~m}$. In the central and southern parts of the basin the wave- and tide-dominated shelf sands of the Gule Horn Member are arranged in two major coarsening upwards - fining upwards (CU-FU) sequences. The storm-influenced shelf heterolithic facies is the most fine-grained part of the cycles, showing a gradational transition into more coarse-grained subtidal sand sheet deposits. The FU parts of the cycles are composed of subtidal sand sheet deposits succeeded by tidal sand ridge sands and/or storm-influenced shelf deposits. Each cycle has a complex internal arrangement with several smaller rhythms. Palaeocurrent directions of the subtidal sand sheets indicate two regional bipolar transport systems towards NNE-SSW and E-W. In the northern part of the basin the Gule Horn Member is made up of wave- and tidalinfluenced delta front deposits. Palaeocurrent directions indicate a predominantly bipolar N-S transport system, with a northern source area.

During Upper Toarcian time, tidal-influenced deposition was superseded by fan delta and shelf deposition of the Ostrea Elv Member. Submarine fan delta and highly bioturbated shelf sediments dominate in the southern and central to eastern parts of the basin. In the northern part of the basin the exposures are very poor and seem to be dominated by storm-influenced shelf sands. No exposures of the Ostrea Elv Member are present in the western part of the basin. The thickness of the member increases from approximately $80 \mathrm{~m}$ in the southern part of the basin to approximately $150 \mathrm{~m}$ in the northern part.

The unconformity between the delta plain deposits of the Kap Stewart Formation and the beach face deposits of the Rævekløft Member developed as a shoreface ravinement surface eroded during the Lower Pliensbachian transgression. In the central and northern parts of the basin a standing water body was already present at the time of the transgression, as indicated by the lateral extensive lacustrine shales of the Kap Stewart Formation, resulting in a gradational boundary between the two formations.

The overall CU-FU sequences in the tide- and waveinfluenced shelf deposits of the Gule Horn Member reflect changes in relative sea level. Using the method of Diem (1985) a palaeodepth of water of a few tens of metres was calculated for the storm-influenced shelf sediments and only a few metres for the coarse-grained tidal sand deposits. Moreover, the preservation of tidal sand ridges suggests a rise in relative sea level (e.g. Stride, 1982; Yang \& Sun, 1988). This is confirmed in the Neill Klinter Formation where the tidal sand ridge complex is succeeded by more open marine sediments of the Ostrea Elv Member.

Basin-wide changes in sea level can be explained by variation of sediment supply and/or rate of subsidence and/or eustatic changes in sea level. The relative sealevel cycles expressed in the Neill Klinter Formation appear to match world-wide Early Jurassic sea-level curves (e.g. Hallam, in press), suggesting that eustatic sea-level changes superimposed on gradual subsidence could generate the cycles present in the Gule Horn Member.

The wave- and tide-influenced delta front sequences in the Gule Horn Member are virtually of the same size as the corresponding lacustrine wave-influenced delta front sequences in the Kap Stewart Formation, suggesting that the general topography of the northern part of the basin was preserved after the change from lacustrine to a wave- and tidal-influenced marine environment.

In Toarcian time, during deposition of the sediments of the Ostrea Elv Member, tidal processes seem to have died out and more open marine conditions prevailed. Sediments were shed into the basin from fan deltas flanking the eastern margin of the basin suggesting tectonic activity along the eastern margin of the basin. The high degree of bioturbation in sequences interfingering with delta front deposits indicates periodically slow sedimentation and little physical reworking. Storm-dominated shelf conditions prevailed in the northern part of the basin in this period.

\section{Laboratory work and future studies}

The main objective for future work is the development and refinement of detailed and regional facies models for the sedimentary history of the Jameson Land basin during Late Triassic and Early Jurassic times. Detailed ichnofacies studies will be incorporated into the facies models. In order to evaluate the reservoir potential, porosity and permeability analyses and diagenetic studies will be carried out in association with Lars Stemmerik (GGU). Preliminary geochemical analyses of the shales of the Kap Stewart Formation have been made and show highly variable TOC contents from approximately $1 \%$ to more than $10 \%$. Most of the samples have a poor generative potential despite their low thermal maturity (Piasecki, 1987). However, a small number of samples show a good to excellent generative potential with high Hydrogen Index values suggesting the presence of Type I kerogen. These samples were all collected in the central and northern parts of the basin where thick lacustrine shales occur in accordance with the sedimentological model. An analytical programme 
based on new sampling in the lacustrine shales and the detailed logging from the field season of 1988 is planned. A comparative study between the Upper Triassic - Lower Jurassic succession in Jameson Land and coeval successions in the Haltenbanken and Barents Sea areas of the Norwegian shelf is also planned.

Field work is to continue in 1989 . The main investigation will be in the central and northern parts of the basin starting with a lithofacies analysis of cores from Haltenbanken and Barents Sea (Norway).

Acknowledgements. The project is supported by British Petroleum Development, London.

\section{References}

Dam, G. 1988: Sedimentological studies of the fluviatile shallow marine Upper Triassic to Lower Jurassic succession in Jameson Land, East Greenland. Rapp. Grønlands geol. Unders. 140, 76-79.

Diem, B. 1985: Analytic method for estimating palaeowave climate and water depth from wave ripple marks. Sedimentology 32(5), 705-720.

Hallam, A. in press: A reevaluation of Jurassic eustasy in the light of new data and revised Exxon curve. In Wilgens, C. K. (edit.) Sea-level changes - an integrated approach. Spec. Publ. Soc. Econ. Paleontol. Mineral.

Harris, T. M. 1937: The fossil flora of Scoresby Sound, East Greenland. 5. Stratigraphic relations of the plant beds. Meddr Grønland 112(1), 1-114.
Pedersen, K. R. \& Lund, J. J. 1980: Palynology of the plantbearing Rhaetian to Hettangian Kap Stewart Formation, Scoresby Sund, East Greenland. Rev. Palaeobot. Palynol. 31, 1-69.

Piasecki, S. 1987: LECO/ROCK-EVAL screening analysis of the Upper Palaeozoic - Mesozoic sediments of Jameson Land, central East Greenland. Unpubl. intern. GGU rep., $60 \& 68$ pp.

Rosenkrantz, A. 1929: Preliminary account of the geology of the Scoresby Sound district. In Koch, L. The geology of East Greenland. Meddr Grønland 73(2), 135-154.

Stride, A. H. 1982: Offshore tidal sands: process and deposits, 213 pp. London: Chapman and Hall.

Surlyk, F., Callomon, J. H., Bromley, R. G. \& Birkelund, T. 1973: Stratigraphy of the Jurassic - Lower Cretaceous sediments of Jameson Land and Scoresby Land, East Greenland. Bull. Grønlands geol. Unders. 105 (also Meddr Grønland 193,5), $76 \mathrm{pp}$.

Surlyk, F., Clemmensen, L. B. \& Larsen, H. C. 1981: PostPaleozoic evolution of the East Greenland continental margin. In Kerr, J. W. \& Ferguson, A. J. (edit.) Geology of the North Atlantic borderlands. Mem. Can. Soc. Petrol. Geol. 7, 611-645.

Yang Chang-shu, Y. \& Sun Jia-song, S. 1988: Tidal sand ridges on East China Sea shelf. In de Boer, P. L., van Gelder, A. \& Nio, S. D. (edit.) Tide-influenced sedimentary environments and facies, 23-38. Dordrecht: D. Reidel Publ. Comp.

G. D. Grønlands Geologiske Undersøgelse, $\emptyset$ ster Voldgade 10, DK-1350 København K, Danmark.

\title{
Shallow core drilling of Upper Permian and Upper Triassic - Lower Jurassic potential reservoir rocks in central East Greenland
}

\author{
Flemming G. Christiansen and Lars Stemmerik
}

The aim of the 1988 shallow core drilling programme was to obtain unweathered and statistically representative samples of potential reservoir rocks to evaluate their diagenetic history. In the concession area held by ARCO (fig. 1) the youngest rocks expected to form a subsurface reservoir are the Upper Triassic - Lower Jurassic Kap Stewart and Neill Klinter Formations (Surlyk et al., 1986b; Stemmerik, 1988). At present, however, most interest is concentrated on the Upper Permian Wegener Halvø Formation (Surlyk et al., 1986a; Hurst et al., 1989) and, consequently, the programme focused on this formation in the type area (fig. 2). Additional drilling was carried out through the Kap Stewart Formation at a location close to Constable Pynt (fig. 1).
The drilling programme on Wegener Halvø was closely related to field investigations in the area by a joint ARCO, AGIP and GGU group (Stemmerik et al., 1989). Thus drilling on Wegener Halvø was restricted to a small, well-investigated area along the east coast of Wegener Halv $\varnothing$ (fig. 2) in order to get continuous samples through the core of two well-exposed but almost inaccessible mounds (fig. 3).

\section{The drilling programme}

The drilling programme was carried out with the helicopter-portable unit assembled by $\mathbf{J}$. Boserup and $\mathbf{A}$. Clausen at the Geological Survey of Greenland. This equipment has been modified a number of times as a 